\title{
INVESTIGATION OF FERMENTATION CHAMBER THERMAL CONDITION PARAMETERS
}

\author{
Marina Tereshchuk ${ }^{1}$, Yaroslav Mykhailovych ${ }^{2}$, \\ Nataliya Tsyvenkova ${ }^{1,2}$, Anna Holubenko ${ }^{1}$ \\ ${ }^{1}$ Polissia National University, Ukraine; \\ ${ }^{2}$ National University of Life and Environmental Sciences of Ukraine, Ukraine \\ marfa3127@yandex.ua,yaroslav_m@ukr.net, \\ nataliyatsyvenkova@gmail.com, anikagogobl@gmail.com
}

\begin{abstract}
The paper presents mathematical modelling and experimental results of thermal condition parameters of the fermentation process of substrate from organic materials, which consisted of $30 \%$ manure, $20 \%$ chopped straw, $20 \%$ poultry dung, $15 \%$ peat and $15 \%$ deciduous trees sawdust with the moisture content $62 \%$ and particle size less than $1 \mathrm{~cm}$. The design of the fermentation chamber for bio-compost production is presented. To prevent heat losses in the composting process the fermentation chamber was thermoinsulated by polystyrene based composite. The ambient temperature was between $-10{ }^{\circ} \mathrm{C}$ to $+10^{\circ} \mathrm{C}$. The aeration air temperature was changing from +20 to $+60{ }^{\circ} \mathrm{C}$. A mathematical model is presented based on the thermal balance equation. The model connects the heat quantity, needed to maintain the temperature mode of the thermophilic phase of the fermentation process, with the aeration air temperature, the ambient temperature and the chamber insulation layer thickness. Experiments were done by the method of a multifactor experiment. It was established that at the ambient temperature $-10{ }^{\circ} \mathrm{C}$, and aeration air temperature $+20{ }^{\circ} \mathrm{C}$ the use of the thermoinsulation reduces the heat losses from 289.4 MJ for no insulation to $190.47 \mathrm{MJ}$ for $50 \mathrm{~mm}$ insulation and to $53.91 \mathrm{MJ}$ for $100 \mathrm{~mm}$, respectively. When the aeration air temperature and ambient temperature rise, the expend for maintaining the temperature mode of the thermophilic phase reduces, and with $50 \mathrm{~mm}$ of insulation there was an excessive heat produced in the amount of $134.77 \mathrm{MJ}$, and with $100 \mathrm{~mm}$ - nearly $151.84 \mathrm{MJ}$. The energy autonomous composting process is achieved at the insulation layer thickness $100 \mathrm{~mm}$, ambient temperature $+1 \ldots+5^{\circ} \mathrm{C}$ and the aeration air temperature $+24 \ldots+18{ }^{\circ} \mathrm{C}$. The obtained measured results are in high correlation with the calculations. The coefficient of determination is 0.99 .
\end{abstract}

Keywords: chamber, compost, fermentation, heat balance, substrate.

\section{Introduction}

Composting is one of the most important ways of making local fertilizers. It is important for conservation of nutritious elements in one fertilizer during its mineralization (solid and liquid manure), as well as rising the accessibility of nutritious elements in more complex fertilizers (peat, straw and other inert organic material) [1]. In solid state fermentation (SSF) processes the necessity exists to consider parameters, which directly affect the development of the system. Such parameters are: designtechnological parameters of the equipment, physical-chemical characteristics of the raw material and the inoculum type [2]. Design parameters include the design of basic assemblies and executive parts of the equipment - rotating drums, mixers, substrate loaders or final product unloaders [3]. Technological parameters are: process temperature, aeration and mixing modes [4; 5]. Physical-chemical properties of the substrate include: component's chemical composition, moisture content, carbon and nitrogen content, acidity, porosity, particle size, etc [6]. Depending on the C:N ratio, a correspondent eco-trophic microorganism group dominates in the substrate $[2 ; 7]$.

According to [8], the most important of all the physical variables affecting the SSF performance is the temperature, because growth and production of enzymes or metabolites are usually sensitive to temperature. Closely related with temperature raise is the heat evolved in the fermentation process. The optimal temperature mode is reached, when the heat quantity excreted from raw material degradation by microorganisms is more than the heat losses connected with aeration and substrate surface cooling. The substrate surface cooling, in turn, depends on the ambient conditions.

The transfer of heat into or out of the SSF system is closely associated with the metabolic activity of the microorganism, as well as the aeration of the fermenting system. According to [9], too much aeration can lead to excessive substrate cooling, preventing the thermophilic conditions required for optimum rates of decomposition, however, too little aeration can lead to anaerobic process conditions. Between these two extremes there is an optimum aeration mode. In works $[10,11]$ a variety of aeration rates are given (from 0.04 to $3.47 \mathrm{~L} \cdot\left(\mathrm{min} \mathrm{kg}\right.$ volatile solids) ${ }^{-1}$ ), the optimal air to substrate ratio is $4: 1$, 
and it is also mentioned that such ambient conditions as the humidity and temperature are important for optimizing the SSF process. Given recommendations depend on the substrate composition.

In the fermentation process much of the energy, generated through the aerobic biodegradation of organic materials, is lost as heat [12]. The estimation of the heat balance in the fermentation process is important in understanding the biochamber dynamics and providing the required amount of heat to reach an optimal temperature mode of the process. Some previous works $[13 ; 14]$ that have examined composting heat dynamics demonstrated the importance of biochamber configuration, its design and the wall conductivity. The authors of the work [13] estimated the heat loss in several different types of composting systems. In their laboratory-scale biochamber the wall conductivity was the largest heat loss $(62 \%)$. Also, wide variations in the amount of heat losses (30-90\% of heat generation) were reported in [14]. In the research work [4] the optimal reactor volume and parameters of insulation material were determined by the way of mathematical modelling (comprehensive model of thermal balance and degradation kinetics was developed). The specified model was considered with metabolic production of the process and five main channels of loss. Lab-scale biochambers (volumes of 10-200 L) and 6 types of insulation materials with different conduction abilities were examined to quantify the chamber thermal influences. The authors recommended to use materials with lower densities and lower thermal conductivity coefficients for building small fermentation systems.

In works $[15 ; 16]$ technical decisions are shown how to maintain stable temperature for organic matter fermentation process, shells of various design are used for maintaining the temperature of the case. A matter that can accumulate heat is used as a heat bearer. To maintain the optimal temperature mode in work [15] the design of the case is proposed, where the walls are hollow, and a thermal bearer of certain temperature circulates. The case design provides heating the rotating drums only partially, however, this technical decision can reduce heat losses up to 30\%. In scientific research [16] by the method of physical modelling the efficiency of usage of a rational biochamber shape (with volume between 1 to $5 \mathrm{~m}^{3}$ ) is substantiated. Patterns of thermal balance forming for the small size biochamber working in mild climate conditions are established. Based on the criterion of effectiveness, an optimal thermal insulation thickness was established (mineral wool $130 \mathrm{~mm}$ ). The reactor heating scheme involving the heat accumulator was shown. The heat accumulator design allows to accumulate heat with the help of a heat exchanger and a pump. There is a possibility to charge the accumulator by the electric heater. The mentioned design solutions are not well substantiated for rotating drum type reactors. Also, either maintaining stable temperature is realized only partially [15], or the equipment becomes bulky and complicated to make in reality [16].

Authors in [4; 17] prove that the composing thermal balance is a theoretical base of scientific investigations for providing optimal temperature mode for all organic matter fermentation phases. They admit that known scientific works review the thermal conditions of small-scale installations (less than $250 \mathrm{~L}$ ) very limitedly due to the complex nature of the fermentation process. For such installations just biological heat could be not enough to maintain the process temperature. While raising the volume of such installations is not always effective from the point of view of operational logistics and bigger expends. That is why a possibility of usage of the thermal maintaining devices should be reviewed. Considering that heating and cooling expends influences the economical part of the fermentation process, the problem is relevant for small-scale installations and needs additional investigation.

The goal of this work is to find the dependency of the balance heat on the ambient temperature, substrate aeration air temperature and the fermentation chamber outer insulation thickness. It will provide optimal temperature modes on all organic material decomposition stages, to raise the substrate fermentation velocity, and to produce high quality compost according to agrochemical regulations.

The investigation introduces a parameter called "balance heat" - a difference between the income and the expend parts of the thermal balance. It can be positive or negative. Positive values mean that there is some excessive heat that should be taken away from the system. Negative values - indicate a lack of heat and a need to add it in order to maintain optimal temperature mode for the process.

Such tasks for the investigation were stated to receive the mentioned goal:

- to compose the heat balance of the thermophilic phase of the fermentation process and to find a balance heat, needed to maintain optimal temperature mode for this phase; 
- to investigate experimentally the dependence of the balance heat from the ambient temperature, the aeration air temperature and the fermentation chamber outer insulation thickness;

- to define the heat quantity that should be fed from additional energy sources to maintain optimal temperature mode of a thermophilic phase of fermentation.

\section{Materials and methods}

The chamber geometrical parameters, physical-chemical and thermo-technical characteristics of materials, temperature modes of thermophilic composting phase, etc. were the initial data for the mathematical model. To simplify the mathematical model some assumptions were made: the substrate considered homogenous; aeration air is ideal gas; insulation considered homogenous by its thermo insulating properties. These assumptions made the model simpler without affecting the accuracy.

Thermal balance is the equality between the input and consumption parts:

$$
\sum Q_{h \text { input }}=\sum Q_{h \text { consump }},
$$

where $Q_{h \text { input }}, Q_{h \text { consump }}$ - heat input and heat consumption, respectively, J.

Let us analize both parts:

$$
Q_{\text {sub }}+Q_{\text {airinc }}+Q_{\text {balance }}+Q_{\text {other }}=Q_{\text {airout }}+Q_{\text {losess }},
$$

where $Q_{s u b}$ - substrate decay heat during the thermophilic composting phase [18], J;

$Q_{\text {air inc }}$ - substrate aeration air heat, J;

$Q_{\text {balance }}$ - balance heat, J;

$Q_{\text {other }}$-heat that comes from other sources (substrate friction against the blade metal surface, etc), J. This component is negligible due to its low value;

$Q_{\text {air out }}$ - heat that is carried away with the exhausted substrate aeration air, J;

$Q_{\text {losess }}$ - heat loses through convection and radiation into environment, J.

The investigated parameter is the balance heat $Q_{\text {balance }}$ :

$$
Q_{\text {balance }}=Q_{\text {airout }}+Q_{\text {losess }}-Q_{\text {sub }}-Q_{\text {airinc }},
$$

Heat quantity that is produced from substrate decay during thermophilic phase of composting, J:

$$
Q_{\text {sub }}=m \cdot k \cdot I \cdot \Delta \tau / t,
$$

where $m$-substrate weight, $\mathrm{kg}$;

$I$ - specific heat from one kilogram of the substrate, $\mathrm{J} \cdot \mathrm{kg}^{-1}$;

$k$-coefficient that considers the unevenness of energy production during the thermophilic phase of the composting process;

$\Delta \tau$-certain time interval of the thermophilic phase, hours;

$t$ - whole thermophilic composting phase duration, hours.

Heat carried in with the substrate aeration air $Q_{a i r \text { inc }}, \mathrm{J}$ :

$$
Q_{\text {airinc }}=C_{\text {air }} \cdot \rho \cdot V_{\text {air }}\left(T_{\text {optcomp }}-T_{\text {airinc }}\right) \Delta \tau \cdot t^{-1},
$$

where $C_{a i r}$ - air specific heat capacity, $\mathrm{J} \cdot\left(\mathrm{kg} \cdot{ }^{\circ} \mathrm{C}\right)^{-1}$;

$\rho$ - air density, $\mathrm{kg} \cdot \mathrm{m}^{-3}$;

$V_{\text {air }}$ - air volume needed for the whole thermophilic composting phase, $\mathrm{m}^{3}$;

$T_{\text {opt comp }}$ - optimal temperature of the thermophilic composting phase, ${ }^{\circ} \mathrm{C}$;

$T_{\text {air inc }}$ - incoming aeration air temperature, ${ }^{\circ} \mathrm{C}$.

Heat quantity $Q_{\text {air out }}$ that is carried away from the chamber with the exhaust aeration air, J:

$$
Q_{\text {airout }}=C_{\text {air }} \cdot \rho \cdot V_{\text {air }}\left(T_{\text {air out }}-T_{\text {ambient }}\right) \Delta \tau \cdot t^{-1} \text {, }
$$

where $T_{\text {ambient }}, T_{\text {air out }}-$ ambient temperature and aeration air temperature respectively, ${ }^{\circ} \mathrm{C}$.

Heat loses into environment $Q_{\text {losess }}$ due to convection and radiation are the highest. Mathematical equation for determination of the loses $Q_{\text {losess }}$ looks like, J: 


$$
Q_{\text {losess }}=F\left(T_{\text {optcomp }}-T_{\text {ambient }}\right) \Delta \tau / \sum_{i=1}^{n} R_{i},
$$

where $F$ - heat exchanging surface area, $\mathrm{m}^{2}$;

$\sum_{i=1}^{n} R_{i}-$ summary coefficient of the thermal resistance, $\left(\mathrm{m}^{2} \cdot{ }^{\circ} \mathrm{C}\right) \cdot \mathrm{W}^{-1}$.

$$
F=\pi\left(D+2 \sum_{i=1}^{n} h_{i}\right) \cdot\left(0.5 \cdot D+\sum_{i=1}^{n} h_{i}+L\right)
$$

where $\quad D$-fermentation chamber inner diameter, $\mathrm{m}$;

$\sum_{i=1}^{n} h_{i}$ - chamber wall thickness considering insulation, m;

$L-$ fermentation chamber length, $\mathrm{m}$.

For the multilayered chamber wall, the summary coefficient of the thermal resistance is [19]:

$$
\sum_{i=1}^{n} R_{i}=\frac{1}{\alpha_{1}}+\sum_{i=1}^{n} \frac{h_{i}}{\lambda_{i}}+\frac{1}{\alpha_{2}}
$$

where $h_{i}-\mathrm{i}$-th layer thickness, $\mathrm{m}$;

$\lambda_{i}-$ i-th layer heat conductivity, $\mathrm{W} \cdot\left(\mathrm{m} \cdot{ }^{\circ} \mathrm{C}\right)^{-1}$;

$\alpha_{1}, \alpha_{2}$ - coefficient of thermal transfer, correspondently, from the substrate to the inner chamber wall and from the outer chamber wall to environment, $\mathrm{W} \cdot\left(\mathrm{m}^{2} \cdot{ }^{\circ} \mathrm{C}\right)^{-1}$.

Substituting (4-7) into (3) we receive:

$$
\begin{aligned}
& Q_{\text {balance }}=m \cdot k \cdot I \cdot \Delta \tau \cdot t^{-1}+C_{\text {air }} \cdot \rho \cdot V_{\text {air }}\left(T_{\text {optcomp }}-T_{\text {airinc }}\right) \Delta \tau \cdot t^{-1}- \\
& -\left(\pi\left(D+2 \sum_{i=1}^{n} h_{i}\right) \cdot\left(\frac{D}{2}+\sum_{i=1}^{n} h_{i}+L\right) \cdot\left(T_{\text {optcomp }}-T_{\text {ambient }}\right) \Delta \tau \cdot\left[\frac{1}{\alpha_{1}}+\sum_{i=1}^{n} \frac{h_{i}}{\lambda_{i}}+\frac{1}{\alpha_{2}}\right]^{-1}\right),
\end{aligned}
$$

From (10) we have:

$$
\begin{aligned}
& \frac{d Q_{\text {balance }}}{d \tau}=m \cdot k \cdot I \cdot t^{-1}+C_{\text {air }} \cdot \rho \cdot V_{\text {air }}\left(T_{\text {optcomp }}-T_{\text {airinc }}\right) t^{-1}- \\
& -\left(\pi\left(D+2 \sum_{i=1}^{n} h_{i}\right) \cdot\left(\frac{D}{2}+\sum_{i=1}^{n} h_{i}+L\right) \cdot\left(T_{\text {optcomp }}-T_{\text {ambient }}\right)\left[\frac{1}{\alpha_{1}}+\sum_{i=1}^{n} \frac{h_{i}}{\lambda_{i}}+\frac{1}{\alpha_{2}}\right]^{-1}\right) .
\end{aligned}
$$

According to (11), the balance heat depends on the ambient temperature, aeration air temperature and the insulation thickness. This parameter could be defined for the whole composting cycle, as well as for the separate time intervals.

To run experiments a pilot plant was designed, which is shown in Fig. 1. The pilot plant consists of an air-tight rotating chamber 5 that has a cylindrical shape and is installed horizontally on hollow axles 7. The chamber 5 is equipped with the lid 6 for loading substrate and unloading treated compost. Thanks to the lid 6, the chamber 5 is easy to maintain, clean from residues, wash, etc. Loading the substrate and unloading the compost is done periodically, which is acceptable for an experimental installation. Also, the lid 6 is equipped with a check valve set at 2 bars. To mix the substrate concave blades 11 and four longitudinally located tubes with jets for substrate aeration are fixed on the inner surface of the chamber 5 (tubes with jets in Fig. 1 unmounted). Axles 7 with bearings are installed in supports 4 . The axle, where the electromechanical power train is connected by the coupler, is blind; the other axle has a connector 10 with inner threads. A coupler 9 serves also for feeding air into the chamber during its rotation. The rotating chamber 5 is actuated with the electromechanical power train that is mounted on the frame 3 . The electromechanical power train consists of a $3.5 \mathrm{~kW}$ electric motor 1 , a planetary gear 2 and a variable frequency drive Hitachi WJ200 (not shown) to adjust the chamber RPM.

During the chamber rotation, due to the combined action of its working units, substrate components experience mixing. The concave blades and four longitudinally located pipes with jets create contra flow particle movement that helps even distribution of components in the substrate. 
To improve the substrate saturation with air, the mixing process is combined with periodical forced aeration. According to [11], the air to substrate ratio is chosen as 4:1. The substrate mixing happens every $55 \mathrm{~min}$ and lasts for $5 \mathrm{~min}$. The chamber rotation rate is $10 \mathrm{rpm}$. During the $5 \mathrm{~min}$. of mixing the air is fed cyclically in 4 takes. Every aeration cycle takes $10 \mathrm{~s}$ and feeds 781 of air. Hence, the total amount is 3121 . Air blowing is done by a vortex blower FPZ SCL 10DL MD 0.37 with the maximal productivity $81 \cdot \mathrm{s}^{-1}$. The time between consequent aerations should be sufficient for the oxygen concentration to drop to $5 \ldots 12 \%$ in the thermophilic stage. The air is supplied into the chamber via the hollow axis by the compressor. Air supply is controlled by the flow regulator. During the pumping, the bypass valve opens automatically, so that the pressure inside the chamber does not exceed 1.1 bars. In case if bypass valve is stuck, due to debris, and the pressure rises, the relief valve is activated to drop the pressure. After mixing and aeration stops, the relief valve opens momentarily to equalize the pressure inside the chamber with the atmospheric one.

Stand 8 is regulated and that makes it possible to change the height of the chamber support. Such design provides the changing chamber rotation axle tilt between $0 . .20$ degrees from the horizontal plane. The angle regulation is discrete with 5 degrees step. Due to this, the substrate can be moved along the chamber that provides additional mixing during the composting process. The total weight of the installation in an unloaded condition is $92 \mathrm{~kg}$, the chamber radius is $275 \mathrm{~mm}$ and the chamber length is $970 \mathrm{~mm}$. The chamber wall thickness is $5 \mathrm{~mm}$. The chamber volume is $220 \mathrm{~L}$.

a)

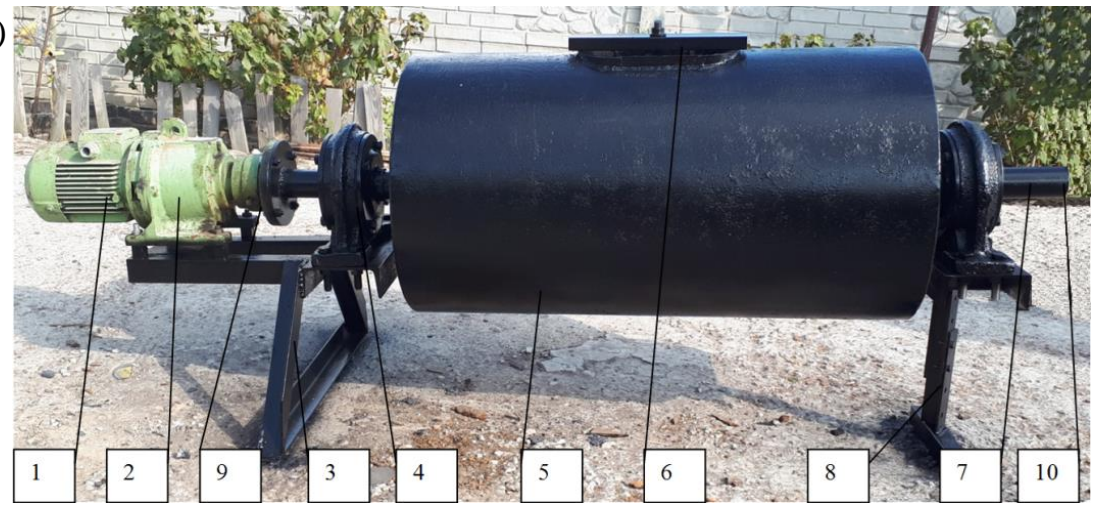

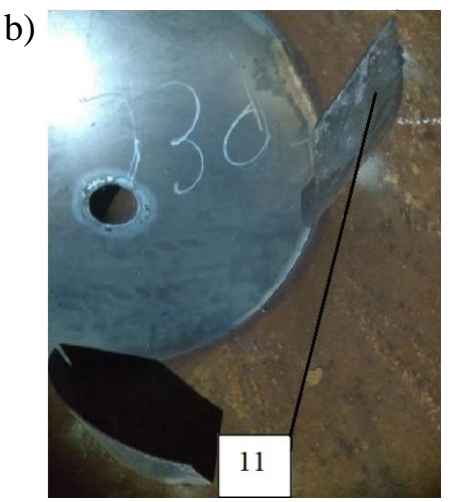

Fig. 1. Pilot plant [18]: $a$ - physical appearance; $b$ - stationary fixed blades

The flow chart of providing the pilot plant with additional heat to maintain optimal temperature mode of the thermophilic phase of the fermentation process is presented in Fig. 2. The chart includes the fermentation chamber and a down draft gasifier [20]. Pellets (10 $\mathrm{mm}$ diameter and $50 \mathrm{~mm}$ length) produced from wheat straw were used as fuel for the gasifier. Quality indicators of the pellets correspond to DIN 51731 and ONorm M 7135. An outcome of dry syngas from $1 \mathrm{~kg}$ of pellets with HHV $14.18 \mathrm{MJ} \cdot \mathrm{kg}^{-1}$ was $2.25 \mathrm{~m}^{3} \cdot \mathrm{kg}^{-1}$. The HHV of dry syngas was $11.84 \mathrm{MJ} \cdot \mathrm{kg}^{-1}$. The gasifier productivity by gas was $68 \mathrm{~m}^{3} \cdot \mathrm{h}^{-1}$. The gasifier diameter is $0.550 \mathrm{~m}$, the height is $1.9 \mathrm{~m}$. The source of the balance heat is the heat received from cooling the syngas from $+650^{\circ} \mathrm{C}$ to $+40^{\circ} \mathrm{C}$.

For even chamber heating along the whole perimeter the chamber wall 2 (Fig. 2) is made double. There is a casing between two metal layers, where a coolant, prepared in a heat exchanger, circulates. A heated (cooled) air is used as a coolant. The heated (cooled) air is used in cold (warm) periods of the year to maintainthe optimal temperature mode in the substrate reaction zone. This technical method helps avoiding the unwanted overcooling (overheating) of the substrate due to environmental factors (frost, direct sunlight, etc.).

To reduce heat exchanging with the environment the fermentation chamber is additionally equipped with a layer of composite thermal insulation. Firstly, expanded polystyrene (consists of $98 \%$ air and 2\% polystyrene, density is $20 \mathrm{~kg} \cdot \mathrm{m}^{-3}$, thermal conductivity is $\left.0.036 \mathrm{~W} \cdot\left(\mathrm{m}^{\circ} \cdot{ }^{\circ}\right)^{-1}\right)$ is cut into blocks, which then are stacked seamlessly with the help of glue. On top of the polystyrene goes the thermo insulating putty (acrylic-polymer mixture) that is solidifying. The putty is dried till full solidification. The resulting composite, besides the thermal insulation, is resistant to the chemically aggressive substances (water, bases, acids), is tough, resistant to mould growth and rotting, significantly reduces operational energy expenses. 
According to Fig. 2, the syngas, produced in the gasifier 4, is cooled in the heat exchanger 5 by the coolant (air, liquid). The coolant (in our case it is air) from the heat exchanger 5 is distributed by the regulator 6 on demand. Air could be used for the substrate 1 aeration, maintaining the temperature in the fermentation chamber 2, for blowing in the gasifier 4 . The experiment started from the substrate 1 loading to the fermentation chamber 2 . The loaded substrate volume was 781 .

a)

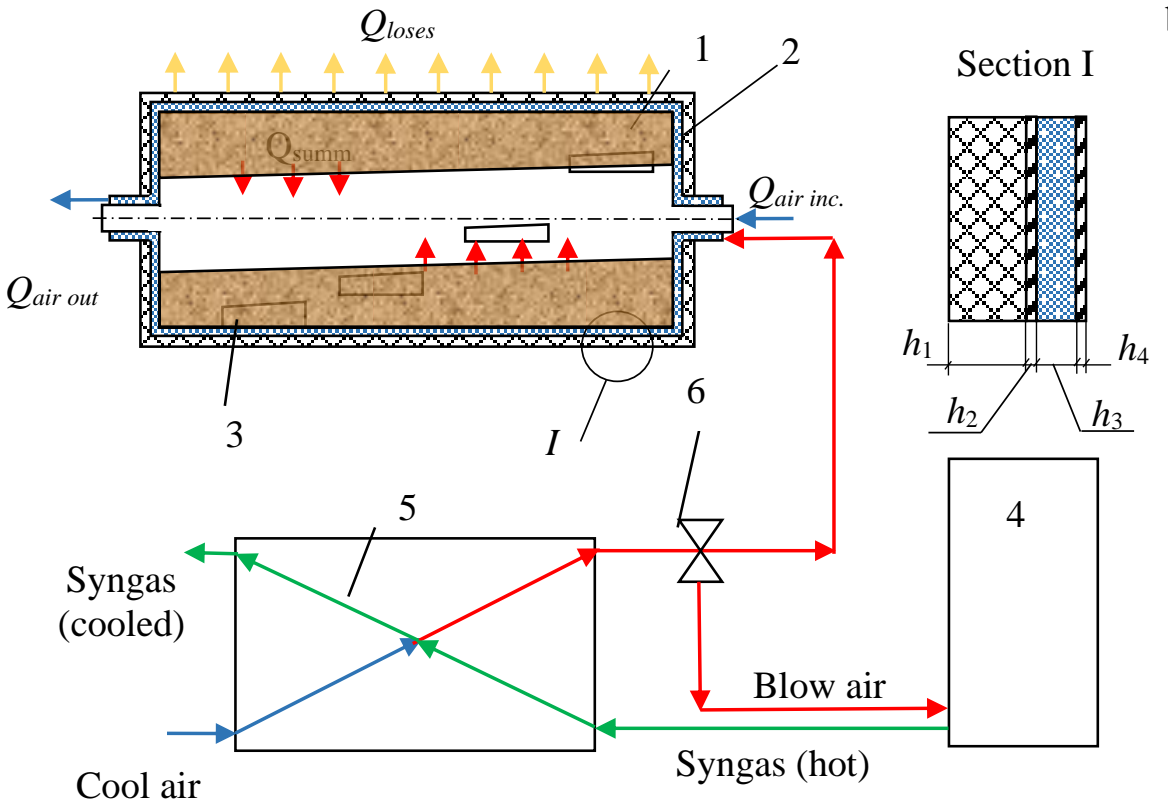

b)

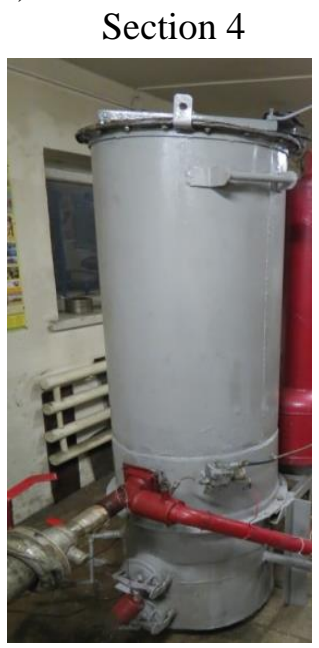

Fig. 2. Heating the fermentation chamber with heat, received by cooling syngas in the heatexchanger - flow chart (a) and gasifier general view (b): 1 - substrate; 2 - fermentation chamber; 3 - substrate mixing blades; 4 - down draft gasifier; 5 - heat exchanger; 6 - coolant flow regulator;

I - chamber wall structure, where: $h_{1}$ - insulation thickness; $h_{2}$-outer metal wall thickness; $h_{3}$ - coolant casing thickness; $h_{4}-$ inner metal wall thickness

The substrate composition and physical-chemical parameters of each component are presented in Table 1. According to Table 1, the total substrate moisture content was 55\%. To raise the substrate moisture content to $62 \%, 41$ of water were sprayed over it. The substrate density was approximately $400 \mathrm{~kg} \cdot \mathrm{m}^{-3}$ at the moisture content $55 \%$ and approximately $451 \mathrm{~kg} \cdot \mathrm{m}^{-3}$ at the moisture content $62 \%$. The C:N ratio at the moisture content $55 \%$, was $30: 1$.

Table 1

\section{Physical-chemical parameters of substrate components}

\begin{tabular}{|c|c|c|c|c|c|c|}
\hline $\begin{array}{c}\text { Substrate } \\
\text { components }\end{array}$ & $\begin{array}{c}\text { Content in } \\
\text { mixture, } \\
\%\end{array}$ & $\begin{array}{c}\text { Moisture } \\
\text { content, } \\
\%\end{array}$ & $\begin{array}{c}\text { Density, } \\
\mathbf{k g} \cdot \mathbf{m}^{-3}\end{array}$ & $\begin{array}{c}\text { Weight of the } \\
\text { component per } \\
1 \text { ton of } \\
\text { substrate, } \mathrm{kg}\end{array}$ & $\begin{array}{l}\text { Weight of the } \\
\text { component per } 1 \\
\text { download, kg }\end{array}$ & $\begin{array}{c}\mathrm{C}: \mathrm{N}, \\
\text { \% to dry } \\
\text { weight }\end{array}$ \\
\hline Manure & 30 & 75 & 690 & 300 & 9.3 & 19.5 \\
\hline $\begin{array}{l}\text { Chopped } \\
\text { straw }\end{array}$ & 20 & 40 & 175 & 200 & 6.2 & 55 \\
\hline Poultry dung & 20 & 55 & 375 & 200 & 6.2 & 10.5 \\
\hline Peat & 15 & 40 & 271 & 150 & 4.65 & 14 \\
\hline $\begin{array}{l}\text { Deciduous } \\
\text { trees sawdust }\end{array}$ & 15 & 50 & 280 & 150 & 4.65 & 210 \\
\hline
\end{tabular}

The substrate was checked by such indicators as the total nitrogen $(\mathrm{N})$ content, total carbon of the humus acids (CHA) content and the moisture content. The content of these elements was defined according to DSTU ISO 4176-2003, DSTU 8454:2015 and GOST 26713-85, respectively. 
The main measuring equipment: the substrate sample weight was measured with a laboratory scales FEH-600 (error $0.01 \mathrm{~g}$ ); substrate moisture content with an instrument ZD-05 (error 0.2\%); substrate temperature was measured with the thermal probe TCP 1-8 (error $0.15 \%$ ); drum rotation speed with the portable optical tachymeter Testo 465 (error $0.02 \%$ ); thermal insulation thickness was measured with the digital calliper $300 \mathrm{~mm}$ (error $0.025 \mathrm{~mm}$ ).

The technical-technological parameters of the composting process were defined by the method of a multifactor experiment. A dependency of the balance heat on the changing parameters was investigated. The changing parameters were: the ambient temperature, substrate aeration air temperature and the insulation layer thickness. The experimental data were processed in Statistica 11.0.

Variable factors of multifactor experiment were: the ambient temperature $T_{\text {ambient }}\left({ }^{\circ} \mathrm{C}\right)$, air temperature $T_{\text {air }}\left({ }^{\circ} \mathrm{C}\right)$ and the insulation layer thickness $l(\mathrm{~mm})$. Variation levels of these factors for definition of the balance heat were: $T_{\text {ambient }}$ was $+10,0$ and $-10^{\circ} \mathrm{C} ; T_{\text {air }}$ was $+60,+40$ and $+20^{\circ} \mathrm{C} ; l$ was 100, 50, $0 \mathrm{~mm}$. Factor encoding were: $T_{\text {ambient }}=X_{1}, T_{\text {air }}=X_{2}, l=X_{3}$.

The use of the full factor experiment requires at least 27 experiments. To reduce the number of experiments from 27 to 13 and to obtain the regression equation based on a quadratic polynomial with the high statistical characteristics, the mathematical method of the experiment planning based on BoxBehnken quadric plan was used [21].

The planning stage included the following steps: factor encoding, scheduling, randomization tests, implementation plan of the experiment, testing of reproducibility of the experiments, calculation of regression coefficients, assessment of the significance of regression coefficients and adequacy of the test model. Experiments were repeated three times. According to the Cochrane's criterion the experiment reproducibility was checked. In case of failing this check, the conditions of the experiment that gave the maximum dispersion value were checked, as well as the measurement accuracy. The adequacy of the received polynomial was done with Fisher's criterion. The significance of every regression coefficient was estimated with Student's criterion. Every experiment's data were statistically pre-processed to exclude blunders. The values of the model relative error for all experiments according to the plan of multifactor analysis are lower than $3 \%$. The values of the mean relative deviation are lower than $2.51 \%$. As it can be seen, the relative error values less than $10 \%$ are considered acceptable [21]. Thus, the presented model predicts the balance heat with a high accuracy.

\section{Results and discussion}

In order to provide high accuracy to the mathematical model, such input parameters as the optimal temperature of the certain composting phase, composting cycle duration and the specific substrate thermal excretion must be defined for every certain substrate composition. As a result of laboratory experiments and statistical computation the data array of the balance heat was received, see Table 2 .

The form of the polynomial equation:

$$
\begin{aligned}
& Q_{\text {balance }}=-50.28+111.25 \cdot X_{1}+38.7 \cdot X_{2}+70.67 \cdot X_{3}+13.68 \cdot X_{1} \cdot X_{2}- \\
& -15.73 \cdot X_{1} \cdot X_{3}-31.35 \cdot X_{2} \cdot X_{3}+0.04 \cdot X_{1}^{2}-3.95 \cdot X_{2}^{2}+18.82 \cdot X_{3}^{2},
\end{aligned}
$$

where $Q_{\text {balance }}$ - balance heat, $\mathrm{MJ}$;

$X_{2}\left(T_{\text {air }}\right)$ - substrate aeration air temperature, ${ }^{\circ} \mathrm{C}$;

$X_{1}\left(T_{\text {ambient }}\right)$ - ambient temperature, ${ }^{\circ} \mathrm{C}$;

$X_{3}(l)$ - insulation layer thickness, $\mathrm{mm}$.

Regression coefficients are: $b_{0}=-50.28 ; \quad b_{1}=111.25 ; \quad b_{2}=38.7 ; \quad b_{3}=70.67 ; \quad b_{12}=13.68 ;$ $b_{13}=-15.73 ; b_{23}=-31.35 ; b_{11}=0.04 ; b_{22}=-3.95 ; b_{33}=18.82$.

Tabulated value of the Cochrane criterion was $G^{\text {tabl }}=0.3346$ at a $5 \%$ level of significance for the number of degrees of freedom $f_{2}=2$ and the number of experiments $f_{1}=15$. We received that $G^{c o m}=0.2184<G^{\text {tabl }}(0.05 ; 15 ; 2)=0.334$, therefore, the process is reproduced [21].

The estimated value of the Fisher criterion in the dispersion of inadequacy $S_{\text {inadeq }}^{2}=3.3$ was $F^{c o m}=9.57$. Since, $F^{c o m}=9.57<F^{t a b l}\left(0.05 ; \mathrm{f}_{1} ; \mathrm{f}_{2}\right)=19.38$, the hypothesis of the adequacy of the regression equation is confirmed [21]. The coefficient of determination is $\mathrm{R}^{2}=0.99$. 
The plots (Fig. 2-4) analysis shows the similarity in the tendencies of the balance heat dependence on the changing factors. The biggest impact on the response function has the ambient temperature, the lower impact has the insulation layer thickness, and the least influence has the aeration temperature.

Table 2

Planning matrix of multifactor experiment

\begin{tabular}{|c|c|c|c|c|c|c|c|c|c|c|}
\hline \multirow{2}{*}{$\begin{array}{l}\text { No. of } \\
\text { expe- } \\
\text { riment }\end{array}$} & \multicolumn{3}{|c|}{ Factors } & \multicolumn{4}{|c|}{ Experiments results } & \multicolumn{3}{|c|}{ Model adequacy check } \\
\hline & $X_{1}$ & $X_{2}$ & $X_{3}$ & $Q_{b a l 1}$ & $Q_{b a l 2}$ & $Q_{b a l 3}$ & $Q_{b . m e d}$ & $Q_{\text {b.med.com }}$ & $\begin{array}{c}\left(Q_{b . \text { med }}-\right. \\
\left.Q_{\text {b.med.com }}\right)\end{array}$ & $\begin{array}{c}\left(Q_{b \text {.med }}-\right. \\
\left.Q_{\text {b.med.com }}\right)^{2}\end{array}$ \\
\hline 1 & + & + & 0 & 109.7 & 110.4 & 110.6 & 110.2 & 109.4 & 0.8 & 0.640 \\
\hline 2 & + & - & 0 & 7.1 & 7.2 & 7.1 & 7.1 & 4.7 & 2.5 & 6.003 \\
\hline 3 & - & + & 0 & -142.2 & -143.4 & -143.0 & -142.9 & -140.4 & -2.4 & 6.002 \\
\hline 4 & - & - & 0 & -191.2 & -191.3 & -191.3 & -191.3 & -190.5 & -0.8 & 0.640 \\
\hline 5 & 0 & 0 & 0 & -50.5 & -50.8 & -50.5 & -50.6 & -50.3 & -0.3 & 0.104 \\
\hline 6 & + & 0 & + & 132.0 & 132.1 & 130.6 & 131.6 & 134.8 & -3.2 & 10.267 \\
\hline 7 & + & 0 & - & 24.6 & 24.8 & 24.8 & 24.7 & 24.9 & -0.1 & 0.021 \\
\hline 8 & - & 0 & + & -56.3 & -56.1 & -56.0 & -56.1 & -56.3 & 0.1 & 0.021 \\
\hline 9 & - & 0 & - & -226.9 & -225.3 & -225.4 & -225.9 & -229.1 & 3.2 & 10.267 \\
\hline 10 & 0 & 0 & 0 & -49.3 & -50.0 & -49.5 & -49.6 & -50.3 & 0.7 & 0.459 \\
\hline 11 & 0 & + & + & 45.2 & 44.9 & 44.9 & 45.0 & 42.6 & 2.4 & 5.740 \\
\hline 12 & 0 & + & - & -36.8 & -36.5 & -36.8 & -36.7 & -36.0 & -0.7 & 0.439 \\
\hline 13 & 0 & - & + & 28.5 & 28.6 & 28.6 & 28.6 & 27.9 & 0.7 & 0.439 \\
\hline 14 & 0 & - & - & -178.7 & -178.7 & -178.2 & -178.5 & -176.1 & -2.4 & 5.740 \\
\hline 15 & 0 & 0 & 0 & -50.7 & -50.8 & -50.4 & -50.6 & -50.3 & -0.4 & 0.126 \\
\hline
\end{tabular}

According to Fig. 2-4, at the ambient temperature that is $-10{ }^{\circ} \mathrm{C}$, aeration air temperature $+20{ }^{\circ} \mathrm{C}$ and no insulation on the chamber to maintain the optimal temperature mode for thermophilic fermentation phase $289.4 \mathrm{MJ}$ of heat needs to be added. For the same conditions, but with $50 \mathrm{~mm}$ of insulation $190.47 \mathrm{MJ}$ of heat are needed and with the $100 \mathrm{~mm}$ of insulation only $53.91 \mathrm{MJ}$ of heat needed. This heat needed to maintain the temperature of the thermophilic phase on the level of $+65 \ldots+70{ }^{\circ} \mathrm{C}$ was received from cooling the syngas. The syngas came from the gasifier as a source of the balance heat that was working in parallel with the fermentation installation. Also, the heat from the gasifier was used to heat the substrate aeration air.

The chamber walls were made of corrosion resistant steel $5 \mathrm{~mm}$ thick. Steel has a high thermal conductivity coefficient around $45 \mathrm{~W} \cdot\left(\mathrm{m} \cdot{ }^{\circ} \mathrm{C}\right)^{-1}$. The use of the thermal insulation $50 \mathrm{~mm}$ thick compared to no insulation reduced the heat losses almost by $34 \%$ at the worst experimental conditions, when $T_{\text {air }}=+20^{\circ} \mathrm{C}$ and $T_{\text {ambient }}=-10{ }^{\circ} \mathrm{C}$. At $T_{\text {air }}=60{ }^{\circ} \mathrm{C}$ and $T_{\text {ambient }}=+10{ }^{\circ} \mathrm{C}$ the $50 \mathrm{~mm}$ of insulation led to the production of $109.43 \mathrm{MJ}$ of excessive heat. The use of $100 \mathrm{~mm}$ thick insulation compared to no insulation reduced the heat losses on the thermophilic phase by 5.4 times at $T_{\text {air }}=+20{ }^{\circ} \mathrm{C}$ and $T_{\text {ambient }}=-10^{\circ} \mathrm{C}$. And at the conditions, when $T_{\text {air }}=60^{\circ} \mathrm{C}, T_{\text {ambient }}=+10^{\circ} \mathrm{C}$ and $l=100 \mathrm{~mm}$, the whole 151.84 $\mathrm{MJ}$ of excessive heat was got from the fermentation process.

The heat loss through the chamber wall was the second significant heat-loss channel after the heat consumption by compost itself [4; 9]. In [4] it is admitted that the heat losses through the metal chamber walls (steel, aluminium) can reach up to $50 \%$ of the total heat. However, the percentage may decrease, if the thickness is reduced, while an extra insulation layer made of other more appropriate materials is added, such that these metals only function to provide stronger structural support for the composting chamber. The percentages of heat loss through the reactor wall of fiberglass, wood block and PVC were approximately $30-35 \%$ at the beginning and decreased to approximately $12 \%$ at the end, as the temperature of the compost and environment were converging. The authors recommended combining aluminium and steel with different thermo-insulating materials, especially for small-scale systems.

Raising the aeration air temperature from $+20^{\circ} \mathrm{C}$ to $+40{ }^{\circ} \mathrm{C}$ and further to $+60{ }^{\circ} \mathrm{C}$ at $T_{\text {ambient }}=-10^{\circ} \mathrm{C}$ and $l=0 \mathrm{~mm}$, led to practically even reduction of heat expenses for the process by $39 \%$. If we look at the aeration air temperature influence at $T_{\text {ambient }}=+10^{\circ} \mathrm{C}$ and $l=100 \mathrm{~mm}$, the 
excessive heat was excreted and this process was uneven. When the temperature raised from $+20{ }^{\circ} \mathrm{C}$ to $+40{ }^{\circ} \mathrm{C}$, the quantity of the excreted heat rose by $18 \%$, while, when temperature raised from $+40{ }^{\circ} \mathrm{C}$ to $+60{ }^{\circ} \mathrm{C}$, the amount of heat rose only by $11 \%$. At the conditions $T_{\text {ambient }}=+10^{\circ} \mathrm{C}$ and $l=100 \mathrm{~mm}$, the use of air with temperature more than $45^{\circ} \mathrm{C}$ caused moisture evaporation intensification from the substrate and inhibited microbial biodegradation. To prevent the substrate moisture content reduction (in some cases it dropped to $45 \ldots 47 \%$ ), the water was added periodically. The authors of [9] met a similar problem. However, we did not investigate the influence of the aeration air temperature on the moisture evaporation rate. The moisture content was an indicator of a normal fermentation process.

a)

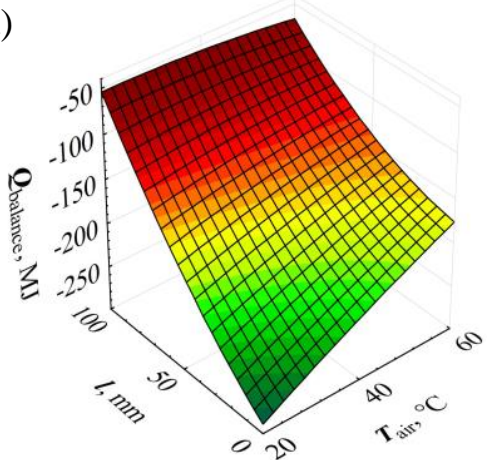

b)

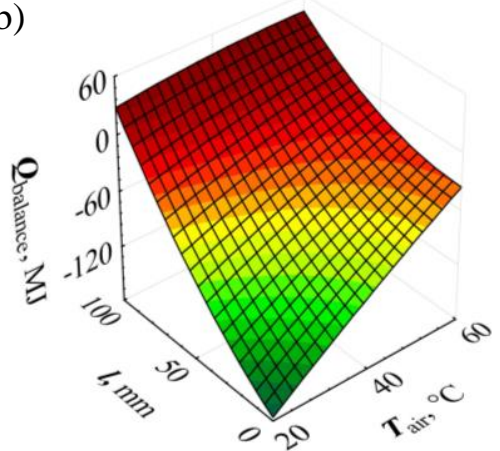

c)

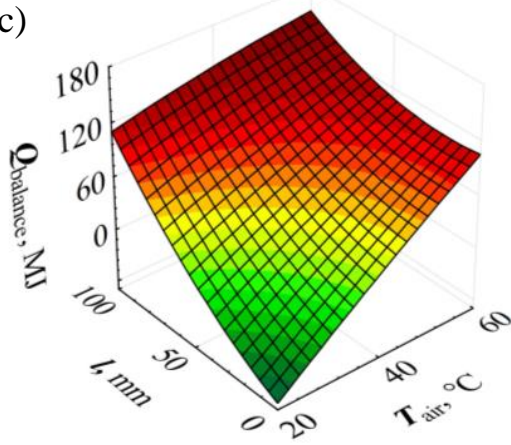

Fig. 2. Balance heat $\boldsymbol{Q}_{\text {balance }}$ against the air temperature $\boldsymbol{T}_{a i r}$ and the insulation layer thickness $l: \mathrm{a}-T_{\text {ambient }}=-10{ }^{\circ} \mathrm{C} ; \mathrm{b}-T_{\text {ambient }}=0{ }^{\circ} \mathrm{C} ; \mathrm{c}-T_{\text {ambient }}=+10{ }^{\circ} \mathrm{C}$

a)

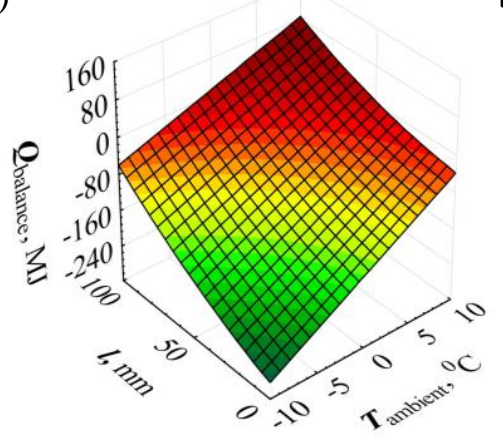

b)

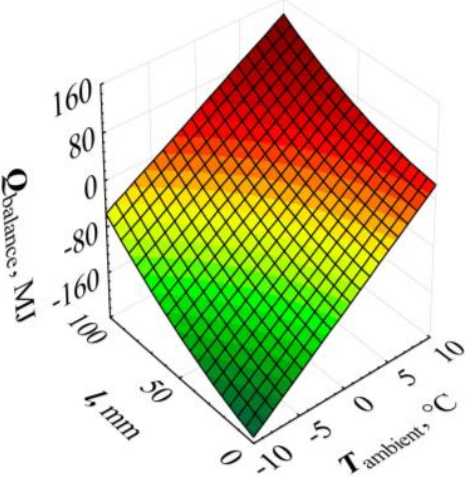

c)

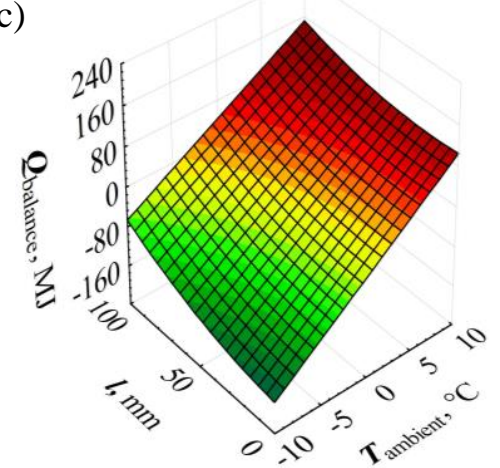

Fig. 3. Balance heat $Q_{\text {balance }}$ against the ambient temperature $\boldsymbol{T}_{\text {ambient }}$ and the insulation layer thickness $l: \mathrm{a}-T_{\text {air }}=20^{\circ} \mathrm{C} ; \mathrm{b}-T_{\text {air }}=40^{\circ} \mathrm{C} ; \mathrm{c}-T_{\text {air }}=60^{\circ} \mathrm{C}$

a)

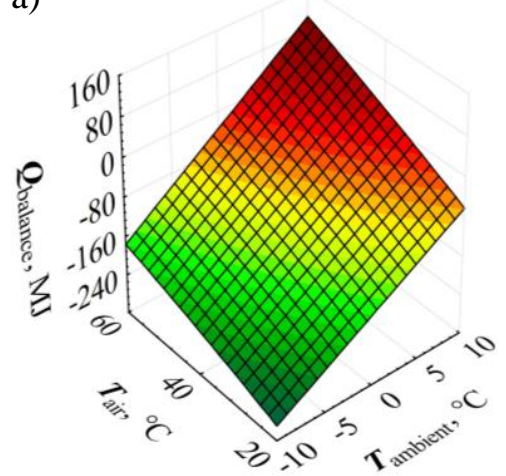

b)

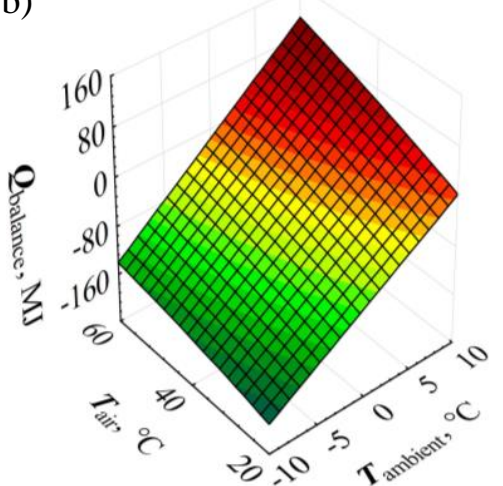

c)

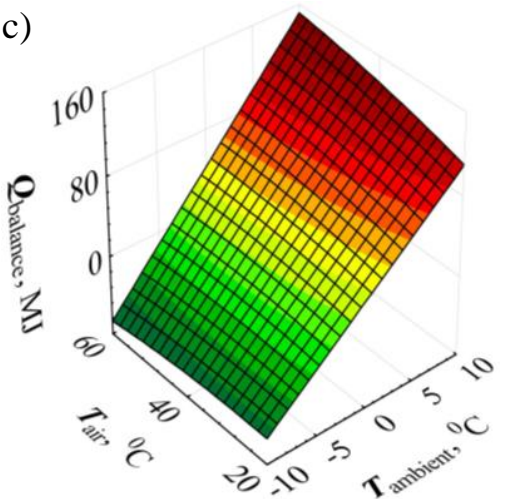

Fig. 4. Balance heat $\boldsymbol{Q}_{b a l a n c e}$ against the ambient temperature $\boldsymbol{T}_{a m b i e n t}$ and the air temperature $\boldsymbol{T}_{\text {air }}$ : $\mathrm{a}-l=0 \mathrm{~mm} ; \mathrm{b}-l=50 \mathrm{~mm} ; \mathrm{c}-l=100 \mathrm{~mm}$

The dependence of the balance heat on the ambient temperature, in our experimental conditions, is non-linear. When the ambient temperature rises, the balance heat surplus appears, that is used to fulfil the other technological needs (blow gas preparation for the gasifier). Rising of $T_{\text {ambient }}$ from $-10{ }^{\circ} \mathrm{C}$ to $+10{ }^{\circ} \mathrm{C}$ for the noninsulated chamber resulted in reducing the heat loses by $226 \mathrm{MJ}$ at $T_{\text {air }}=+20^{\circ} \mathrm{C}$, 
and to excretion of excessive heat in amount of $25 \mathrm{MJ}$ at $T_{\text {air }}=+40{ }^{\circ} \mathrm{C}$, and about $105 \mathrm{MJ}$ at $T_{\text {air }}=+60^{\circ} \mathrm{C}$, respectively. When thermoinsulation was used, the loss reduction was more significant. Yet, for $l=50 \mathrm{~mm}$ and $T_{a i r}=+40{ }^{\circ} \mathrm{C}$, the heat excess of $61 \mathrm{MJ}$ was received and for $T_{\text {air }}=+60{ }^{\circ} \mathrm{C}-$ around $110 \mathrm{MJ}$. When $100 \mathrm{~mm}$ insulation was used, the change of the ambient temperature from $-10^{\circ} \mathrm{C}$ to $+10{ }^{\circ} \mathrm{C}$ provided the heat needs of the fermentation process fully and $151.84 \mathrm{MJ}$ of excessive heat was received. In real conditions of the fermentation chamber operation the balance heat depends not only on the temperature, but also on the air humidity, wind speed and direction. The influence of these parameters stipulates the deviation of the experimental data from the modelled data. The insulation use expediency, under other equal conditions, is higher with higher air humidity. It is due to fact that the water thermal conductivity is 20 times higher than that of the air in the insulation pores. Besides that, the moisture in the pores enlarges the contacting surface that leads to raising the effective thermal conductivity. When the air humidity rises from 60 to $85 \%$ the insulation efficiency rises by $7 \%$ [5].

The composting process, which is energy independent, is achieved at the insulation layer thickness $100 \mathrm{~mm}$, ambient temperature $-+1 \ldots+5^{\circ} \mathrm{C}$ and the aeration air temperature $-+24 \ldots+18{ }^{\circ} \mathrm{C}$.

So, based on the thermal balance and according to the ambient conditions we can define such insulation thickness and aeration air temperature that the balance heat will fully compensate the heat needed to maintain the thermophilic phase temperature. In case of increased energy consumption, we can calculate the amount of heat that must be supplied from additional energy sources.

\section{Conclusions}

The experimental study and numerical simulation of the organic material fermentation process have led to the following conclusions.

1. With the help of the multifactor experiment with further data analysis it was found that the ambient temperature influences the balance heat the most. Rising of the ambient temperature from $-10{ }^{\circ} \mathrm{C}$ to $+10^{\circ} \mathrm{C}$, results in reducing the heat losses for fermentation by $226 \mathrm{MJ}$ at $T_{a i r}=+20^{\circ} \mathrm{C}$ and to excretion of excessive heat in amount of $25 \mathrm{MJ}$ at $T_{\text {air }}=+40^{\circ} \mathrm{C}$, and about $105 \mathrm{MJ}$ at $T_{\text {air }}=+60{ }^{\circ} \mathrm{C}$ respectively even with no thermal insulation on the chamber.

2. The thermal insulation thickness is the second important parameter that influences the temperature conditions of the fermentation process. The use of the thermal insulation $50 \mathrm{~mm}$ thick compared to no insulation reduced the heat losses almost by $34 \%$ at $T_{\text {air }}=+20^{\circ} \mathrm{C}$ and $T_{\text {ambient }}=-10{ }^{\circ} \mathrm{C}$ and led to the production of $109.43 \mathrm{MJ}$ of excessive heat at $T_{\text {air }}=60^{\circ} \mathrm{C}$ and $T_{\text {ambient }}=+10^{\circ} \mathrm{C}$. The use of $100 \mathrm{~mm}$ thick insulation compared to no insulation reduced the heat losses on the thermophilic phase by 5.4 times at $T_{\text {air }}=+20^{\circ} \mathrm{C}$ and $T_{\text {ambient }}=-10^{\circ} \mathrm{C}$. The use of $100 \mathrm{~mm}$ thick insulation at $T_{\text {air }}=+60^{\circ} \mathrm{C}$ and $T_{\text {ambient }}=+10^{\circ} \mathrm{C}$ gave $151.84 \mathrm{MJ}$ of the excessive heat.

3. Raising the aeration air temperature from $+20^{\circ} \mathrm{C}$ to $+40{ }^{\circ} \mathrm{C}$ and further to $+60{ }^{\circ} \mathrm{C}$ at $T_{\text {ambient }}=-10{ }^{\circ} \mathrm{C}$ and no chamber insulation led to practically even reduction of heat expenses for the process by $39 \%$. When temperature raised from $+20^{\circ} \mathrm{C}$ to $+40{ }^{\circ} \mathrm{C}$, the quantity of excreted heat rose by $18 \%$, while, when the temperature raised from $+40{ }^{\circ} \mathrm{C}$ to $+60{ }^{\circ} \mathrm{C}$, the amount of heat rose by $11 \%$. At the conditions when the ambient temperature was $+10^{\circ} \mathrm{C}$ and $100 \mathrm{~mm}$ insulation the use of air with temperature more than $45^{\circ} \mathrm{C}$ caused moisture evaporation intensification from the substrate and inhibited microbial biodegradation.

4. The composting process, which is energy independent, is achieved at the insulation layer thickness is $100 \mathrm{~mm}$, ambient temperature $-+1 \ldots+5^{\circ} \mathrm{C}$ and the aeration air temperature $-+24 \ldots+18{ }^{\circ} \mathrm{C}$. The obtained measured results are in high correlation with the calculations. The coefficient of determination is $R^{2}=0.99$.

\section{References}

[1] Ahmad R., Jilani G., Arshad M., Zahir Z. A., Khalid Az. Bio-conversion of organic wastes for their recycling in agriculture: an overview of perspectives and prospects. Annals of Microbiology, vol. 57 (4), 2007, pp. 471-479.

[2] Krishna C. Solid-State Fermentation Systems - An Overview. Critical Reviews in Biotechnology, vol. 25 (1-2), 2005, pp. 1-30. 
[3] Arora S., Rani R., Ghosh S. Bioreactors in solid state fermentation technology: Design, applications and engineering aspects. Journal of Biotechnology, vol. 269, 2018, pp. 16-34.

[4] Wang Y., Pang L., Liu X., Wang Y., Zhou K., Luo F. Using thermal balance model to determine optimal reactor volume and insulation material needed in a laboratory-scale composting reactor. Bioresource Technology, vol. 206, 2016, pp. 164-172.

[5] Kalamdhad A. S. et al. Stability evaluation of compost by respiration techniques in a rotary drum composter. Resources, conservation and recycling, vol. 52(5), 2008, pp. 829-834.

[6] Gautam S. P., Bundela P. S., Pandeyet A. K. Composting of municipal solid waste of Jabalpur city. Global Journal of Environmental Research, vol. 4 (1), 2010, pp. 43-46.

[7] Nakasak K., Nag K., Karita S. Microbial succession associated with organic matter decomposition during thermophilic composting of organic waste. Waste Management \& Research: The Journal for a Sustainable Circular Economy, Vol. 23, 2005, pp. 48-56.

[8] Muller dos Santos M., Souza da Rosa A., Dal'Boit S., Mitchell D. A., Krieger N. Thermal denaturation: is solid-state fermentation really a good technology for the production of enzymes? Bioresource Technology, vol. 93 (3), 2004, pp. 261-268.

[9] Ahn H. K., Richard T. L., Choi H. L. Mass and thermal balance during composting of a poultry manure - Wood shavings mixture at different aeration rates. Process Biochemistry, vol. 42 (2), 2007, pp. 215-223.

[10] Haug R. T. The practical handbook of compost engineering. Lewis Publishers, Boca Raton, 1993.

[11] Lu S. G. et. al. Effect of Enforced Aeration on In-Vessel Food Waste Composting. Environmental Technology, vol. 22 (10), 2001, pp. 1177-1182.

[12] Leön R., Torres J. A., Echevarrí J., Saura G. Energy balance in solid state fermentation processes. Acta Biotechnologica, vol. 11 (1), 1991, pp. 9-14.

[13] Bach P. D., Nakasaki K., Shoda M., Kubota H. Thermal balance in composting operations. Journal of Fermentation Technology, vol. 65 (2), 1987, pp. 199-209.

[14] Alkoaik F., Abdel-Ghany Ah., Rashwan M., Fulleros R., Ibrahim, M. Energy Analysis of a Rotary Drum Bioreactor for Composting Tomato Plant Residues. Energies, vol. 11(2), 2018, pp. 1-14.

[15] Стасевич М. В., Милянич А. О., Гузьова І. О. та ін. Обладнання технологічних процесів фармацевтичних та біотехнологічних виробництв (Equipment of technological processes of pharmaceutical and biotechnological productions): навч. посіб.; за ред. В. П. Новікова. Вид. 2ге, стереотип. Вінниця: Нова Книга, 2016. 408 с. (In Ukrainian).

[16] Фурдас Ю.В.Визначення потужності системи підігріву побутового біореактора (Determination of the capacity of the domestic bioreactor heating system). Науковий вісник НЛТУ України, vol. 23.7, 2013, pp. 106-111. (In Ukrainian).

[17] Raghavarao K. S. M., Ranganathan T., Karanth N. Some engineering aspects of solid-state fermentation. Biochemical Engineering Journal, vol. 13 (2-3), 2003, pp. 127-135.

[18] Vechera O., Tereshchuk M., Chuba V., Tsyvenkova N. Investigation of aerobic solid fraction fermentation process parameters for organic material. Proceedings of the 19-th International scientific conference "Engineering for rural development", May 20-22, 2020, Jelgava, Latvia, pp. 1450-1455. Available at: http://www.tf.llu.lv/conference/proceedings2020/Papers/TF363.pdf

[19] Теплотехнический справочник (Heat engineering reference book). Том 2./Под ред. В.Н. Юренева, П.Д. Лебедева. М. : Энергия, 1976, 896 с.

[20] Pavlenko M., Chuba V., Tsyvenkova N., Tereshchuk M. An experimental study on biomass airsteam gasification effectiveness in a downdraft gasifier. Proceedings of the 19-th International scientific conference "Engineering for rural development", May 20-22, 2020, Jelgava, Latvia, pp. 1831-1839. Available at: http://www.tf.llu.lv/conference/proceedings2020/Papers/TF495.pdf

[21] Мельников С.В., Ацелкин В.Р., Рощин П.М. Планирование эксперимента в исследованиях сельскохозяйственных процессов (An experiment planning in researches of agricultural processes). Leningrad: Kolos, 1980, 168 p. (In Russian). 